\title{
In silico target prediction: identification of on- and off-targets for crop protection agents
}

\author{
Rucha K Chiddarwar ${ }^{1}$, Andreas Bender ${ }^{{ }^{*}}$, Sebastian Rohrer $^{2}$ \\ From 8th German Conference on Chemoinformatics: 26 CIC-Workshop \\ Goslar, Germany. 11-13 November 2012
}

There has been a dramatic change in the agricultural research along the years and it has broadened its scope and scale which has become more multidisciplinary, inclusive and integrative [1]. On one hand we have literature that has shown agricultural research to have addressed key issues for society such as sustainability of production, nutrition and health [1], and on the other hand the field has generated a large amount of life science data we can now use for data mining purposes. Of relatively recent relevance for the field of agrochemicals is the area of cheminformatics where novel applications range from lead identification to target prediction [2]. Agrochemicals, just as other bioactive compounds, in many cases cause effects in biological organisms by modulating target proteins. These effects might be wanted or unwanted, depending on the target organism (pathogen or human), and hence identification of these targets is crucial for either the mode-ofaction analysis or the anticipation of adverse effects of agrochemical products. In this spirit, the current project aims at a faster elucidation of agrochemical target proteins based on chemical structures. Using publicly available data as an input to chemogenomics-based in-silico target prediction models, hypotheses about putative targets for crop protection agents can be generated to guide subsequent biochemical validation experiments as well as to guide compound modifications.

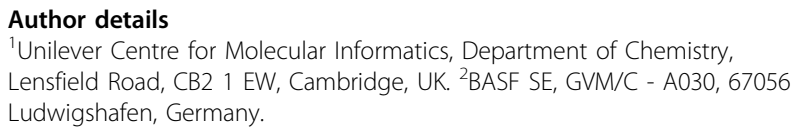

Published: 22 March 2013

\footnotetext{
* Correspondence: ab454@cam.ac.uk

'Unilever Centre for Molecular Informatics, Department of Chemistry, Lensfield Road, CB2 1 EW, Cambridge, UK

Full list of author information is available at the end of the article
}

\section{References}

1. Dodet M: Challenges for Agricultural Research. OECD Cooperative Research Programme Prague 2009.

2. Koutsoukas A, et al: From in silico target prediction to multi-target drug design\%o: Current databases, methods and applications. J Prot 2011, 74:2554-2574.

doi:10.1186/1758-2946-5-S1-P18

Cite this article as: Chiddarwar et al.: In silico target prediction: identification of on- and off-targets for crop protection agents. Journal of Cheminformatics 2013 5(Suppl 1):P18.

\section{Publish with ChemistryCentral and every scientist can read your work free of charge \\ "Open access provides opportunities to our colleagues in other parts of the globe, by allowing anyone to view the content free of charge." \\ W. Jeffery Hurst, The Hershey Company. \\ - available free of charge to the entire scientific community \\ - peer reviewed and published immediately upon acceptance \\ - cited in PubMed and archived on PubMed Central \\ - yours - you keep the copyright \\ Submit your manuscript here: \\ http://www.chemistrycentral.com/manuscript/

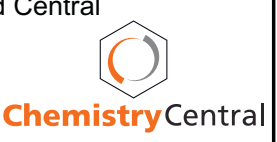

